\title{
Ecology of amorphous aggregations (marine snow) in the Northern Adriatic Sea. II. Microbial density and activity in marine snow and its implication to overall pelagic processes
}

\author{
Gerhard J. Herndl* \\ Institute of Zoology, University of Vienna, Althanstr. 14, A-1090 Vienna, Austria
}

\begin{abstract}
In the Northern Adriatic Sea, marine snow dry mass varied between 3.4 and $9.1 \mathrm{mg} \mathrm{l^{-1 }}$ during summer. In situ measurements of $\mathrm{O}_{2}$-fluxes mediated by marine snow revealed a gross primary production (GPP) ranging from 3 to $23 \mu \mathrm{g} \mathrm{O} \mathrm{mg}^{-1}$ (marine snow ash-free dry wt, AFDW) $\mathrm{h}^{-1} \mathrm{O}_{2^{-}}$ consumption rates ranged from 1.35 to $3.7 \mu \mathrm{g} \mathrm{O}_{2} \mathrm{mg}^{-1}$ (marine snow AFDW) $\mathrm{h}^{-1}$ and were ca 5 times the mean consumption obtained under laboratory conditions. Based on these $\mathrm{O}_{2}$-flux measurements, we estimate that more than $90 \%$ of the pelagic GPP is bound to marine snow aggregations and ca $70 \%$ of the mineralization activity is mediated by marine snow associated microbes during summer. Total carbohydrate (TCHO) content in marine snow was found to be enriched by a factor of 304 as compared to the surrounding water $\left(\overline{\mathrm{x}}=0.82 \mu \mathrm{g} \mathrm{TCHO} \mathrm{ml}^{-1}\right)$. Batch cultures with marine snow were designed to investigate the influence of marine snow on the free-living microbial community. In the chambers containing marine snow, growth rates $(\mu)$ of the bacterial community were 3 times the rates obtained for unenriched media (containing $1 \mu \mathrm{m}$ filtered seawater only). Based on the batch culture experiment, it is concluded that marine snow enhances not only microbial growth on/in the organic matrix of the aggregations but also favors microbial activity of the surrounding water The degree of development of the microheterotrophic food chain was quantified using the ratio (nanoflagellate biomass/bacterial biomass) $\times 100$. In the incubation media containing marine snow, ratios of $>100$ were maintained most of the time, indicating that additional food sources other than free-living bacteria were exploited by the nanoflagellate population. It is suggested that more sensitive sampling methods should be used to resolve such nutrient patches which cause heterogeneity of the pelagic environment.
\end{abstract}

\section{INTRODUCTION}

Marine amorphous aggregations ('marine snow') are a ubiquitous component of pelagic marne waters (Fowler \& Knauer 1986). The chemical and biological components of these aggregations may vary according to their origin. Estuaries are a site of particle formation. Terrigenous humic matter transported by rivers into estuaries rapidly flocculates with increasing salinity (Jackson 1975, Sholkovitz 1976). These terrigenous humic substances have been shown to constitute about 60 to $80 \%$ of the dissolved organic carbon (DOC) in rivers (Reuter \& Perdue 1977). The flocculation of

\footnotetext{
- Present address: Institute of Marine Resources, A-018, Scripps Institution of Oceanography, University of California, San Diego, La Jolla, California 92093, USA
}

humics at the freshwater-seawater boundary has been attributed to adsorption/(co)precipitation of humic substances by iron (III) oxyhydroxides (Krom \& Sholkovitz 1977. Poutanen \& Morris 1983). Organic coating of negatively charged particles (of um size) facilitates aggregation with other particles (McCave 1984, Kranck et al. unpubl.).

If water-current velocities are sufficiently high to prevent particle settlement, these aggregates are transported off-shore (Eisma 1986). This means that the organic fraction of the aggregates increases with distance from the estuary. Amorphous aggregates of estuarine origin, however, never reach as high an organic content as that usually detected in marine snow of biological origin (Amy et al. 1987). An important role in the formation of amorphous aggregations may be performed by bacteria, which convert dissolved 
organic matter (DOM) into a particulate form, and aggregate particles with their slime (Paerl 1975. Biddanda 1985, 1988, Biddanda \& Pomeroy 1988).

While marine snow particles of estuarine origin contain litile biological material, aggregations of biological origin harbor a rich microbial community of living phytoplankton, Protozoa and bacteria (Silver et al. 1978, 1984, Caron et al. 1982, Beers et al. 1986). Usualiy these aggregates range from $0.5 \mathrm{~mm}$ to several $\mathrm{cm}$ in diameter.

In the Northern Adriatic Sea these particles tend to aggregate to a size of up to $20 \mathrm{~cm}$ in diameter during calm weather conditions. Typically, 'stringers' are formed at the initial stage of aggregation, while the more advanced stage of succession is characterized by large coagulations (Eisma 1986, Herndl \& Peduzzi 1988). Their large dry mass - up to $10 \mathrm{~g}$ (marine snow dry wt) $\mathrm{m}^{-3}$ - in the waters of the Gulf of Trieste during summer and the high densities of both autotrophic and heterotrophic organisms embedded in the organic matrix, led to the hypothesis that these aggregations may contribute significantly to the metabolism of the pelagic phase (Herndl \& Peduzzi 1988).

The present study evaluates the contribution of marine snow to overall metabolism of the pelagic phase; it also assesses the extent to which decomposition of the organic matrix of marine snow enhances planktonic production of microheterotrophs.

\section{MATERIAL AND METHODS}

Study locations and sampling procedure. Investigations were conducted in the Gulf of Trieste (Northern Adriatic Sea) between April and October 1987. Marine snow abundance was determined at irregular time intervals in various depth layers using the procedure described in Herndl \& Peduzzi (1988). Briefly, a translucent tube $150 \mathrm{~cm}$ in length, $5 \mathrm{~cm}$ in diameter) was slowly moved horizontally through a specified depth layer of the water column. Within 30 min the contents of each tube were filtered through a precombusted Whatman glass-fiber filter $(\mathrm{GF} / \mathrm{F})$ and rinsed with distilled water to obtain the dry wt $\left(12 \mathrm{~h}\right.$ at $\left.70^{\circ} \mathrm{C}\right)$ of marine snow. Zooplankters not attached to the organic matrix of marine snow were carefully removed under a dissecting microscope by means of forceps prior to drying. After dry wt determination, ash-free dry wt (AFDW) was determined after combustion at $450^{\circ} \mathrm{C}$ for $6 \mathrm{~h}$.

For chemical and biological analyses, marine snow and surrounding water were collected using syringes of various size $(10$ to $930 \mathrm{ml}$ ). Although a great deal of effort, was exerted to minimize the volume of ambient water during marine snow sampling, we unavoidably sucked a varying volume of water into the marine snow'-syringes. Therefore, we used 2 methods for analysis of marine snow: (1) We examined marine snow-seawater slurries sampled by syringes; (2) marine snow-seawater slurry was poured in $5 \mathrm{ml}$ glass jars, and marine snow allowed to settle for $10 \mathrm{~min}$ prior to collection with Pasteur pipettes. Samples for enumeration of organisms were preserved as described below as soon as they were brought aboard. Samples of ambient water were taken and treated in the same way as marine snow.

In situ and laboratory $\mathrm{O}_{2}$-flux measurements. In situ measurements of $\mathrm{O}_{2}$-flux in marine snow and ambient water were performed around noon for $4 \mathrm{~h}$. Marine snow-seawater slurries and seawater were sampled at the same depth and subsequently incubated using $930 \mathrm{ml}$ syringes with an opening of $1 \mathrm{~cm}$ in diameter. Syringe contents from a given depth were poured into translucent and dark glass jars, respectively. Care was taken to avoid enclosure of air bubbles. Light and dark bottles containing marine snow-seawater slurries and seawater, respectively, were deployed in duplicate at 3 , 6,9 and $12 \mathrm{~m}$ depth. The $\mathrm{O}_{2}$-contents of the incubation media were measured at the beginning and the end of the deployment by a battery-driven respiration set equipped with polarographic oxygen sensors (Yellow Springs Instrument; Svoboda \& Ott 1983).

At the end of the incubation, the marine snow-seawater slurries were filtered onto precombusted and preweighed glass fiber filters (Whatman GF/F) for dry wt and AFDW determination as described above. This procedure enabled expression of the $\mathrm{O}_{2}$-flux in seawater and the flux mediated by marine snow. During in situ incubation, photosynthetically active radiation (PAR) was recorded 3 times by a LiCor LI 1000 Data Logger; temperature readings in several depth layers were performed at the beginning and the end of the experiment. Gross primary production (GPP) was calculated assuming equal respiration rates during day and night. In order to convert $\mathrm{O}_{2}$-values into carbon equivalents a respiratory and production quotient of 1 was used (Oviatt et al. 1986)

In addition to in situ $\mathrm{O}_{2}$-flux measurements, laboratory experiments were performed for comparison using the continuous $\mathrm{O}_{2}$-recording system and incubation chambers with a volume of $23 \mathrm{ml}$ (Svoboda \& Ott 1983, Peduzzi 1987). Incubation chambers were filled with $0.45 \mathrm{~mm}$ Nuclepore-filtered seawater and marine snow particles were carefully transferred from storage vials to incubation chambers. Marine snow was stored in dark at in situ water temperature for ca $1 \mathrm{~h}$ prior to the $\mathrm{O}_{2}$-flux measurements. Between 1.0 and $7.3 \mathrm{mg}$ (marine snow dry $w t$ ) were incubated in the incubation chambers and the $\mathrm{O}_{2}$-flux recorded for 2 to $4 \mathrm{~h}$. 
$\mathrm{O}_{2}$-concentration of the incubation media never deviated by more than $30 \%$ of the initial concentration.

Batch culture experiments. To evaluate the influence of marine snow on microbial dynamics of the surrounding water, incubation experiments were performed at $20^{\circ} \mathrm{C}$ in the dark at the Stazione Biologia Marina at Trieste-Aurisina (Italy). Incubations were performed in triplicate; additionally, one jar containing $800 \mathrm{ml}$ of $1 \mu \mathrm{m}$ Nuclepore-filtered seawater only served as a control. Two hundred $\mathrm{ml}$ of a freshly collected marine snow-seawater slurry (corresponding to 30 to $35 \mathrm{mg}$ marine snow dry wt) were added to each of the 3 jars containing $1 \mu \mathrm{m}$ filtered seawater. Incubated marine snow was kept in suspension by gently aerating the incubation media with $0.45 \mu \mathrm{m}$ filtered air. Water samples were taken at various time intervals for bacteria and nanoflagellate enumeration and carbohydrate $(\mathrm{CHO})$ analysis. Additionally, marine snow particles were removed occasionally from the media for particulate CHO-determination.

Microbial and chemical analysis. For microbial analysis, all surrounding water samples, marine snow particles, and slurries were fixed with concentrated, unbuffered formalin to a final concentration of $2 \%(\mathrm{v} / \mathrm{v})$. Bacteria and heterotrophic flagellates were enumerated using epifluorescence microscopy and acridine orange direct counting (Hobbie et al. 1977). Flagellates lacking distinct red fluorescent chloroplasts were assigned as heterotrophs. Dimensions of organisms enumerated by epifluoresence microscopy (magnification: $1250 \times$ ) were measured using a calibrated ocular micrometer. Volumes of these organisms were calculated assuming a spherical shape for heterotrophic coccoid bacteria, a cylindrical shape for rods, and an ellipsoid shape for microflagellates. For microflagellates, the cell-volume to cell-carbon conversion factor $\left(220 \mathrm{fg} \mathrm{C} \mathrm{um}^{-3}\right.$ ) was used (Borsheim \& Bratbak 1987). The carbon content of bacteria was calculated

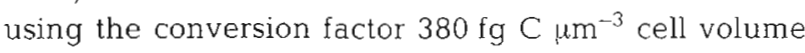
(Lee \& Fuhrman 1987).

The enrichment factor (EF) was calculated for each category of microorganism ( $n=$ number of organisms): $\mathrm{EF}=n \mathrm{ml}^{-1}$ (marine snow) $/ n \mathrm{ml}^{-1}$ (surrounding water) Marine snow volume was measured by means of graded pipettes.

Water samples for dissolved $\mathrm{CHO}$ analysis were filtered through precombusted glass fiber filters (Whatman $\mathrm{GF} / \mathrm{F}$ ) within $30 \mathrm{~min}$ after sampling and stored frozen $\left(-20^{\circ} \mathrm{C}\right)$ until analysis. For particulate $\mathrm{CHO}$, marine snow aggregations were filtered onto glass fiber filters (which were treated as described above). $\mathrm{CHO}$-contents were measured spectrophotometrically according to the methods of Burney \& Sieburth (1977) and Johnson \& Sieburth (1977). In order to present the data on $\mathrm{CHO}$ in terms of carbon we assumed that hexoses, containing $72 \mathrm{~g} \mathrm{C} \mathrm{mol}^{-1}(\mathrm{MW}=180$, carbon content $40 \%(\mathrm{w} / \mathrm{w})$, dominated the carbohydrates.

\section{RESULTS}

\section{Marine snow abundance and organic content}

Marine snow dry mass varied between 3.4 and 9.1 $\mathrm{mg} \mathrm{l}^{-1}$ and increased steadily with depth (Fig. 1). The organic content of marine snow, however, decreased

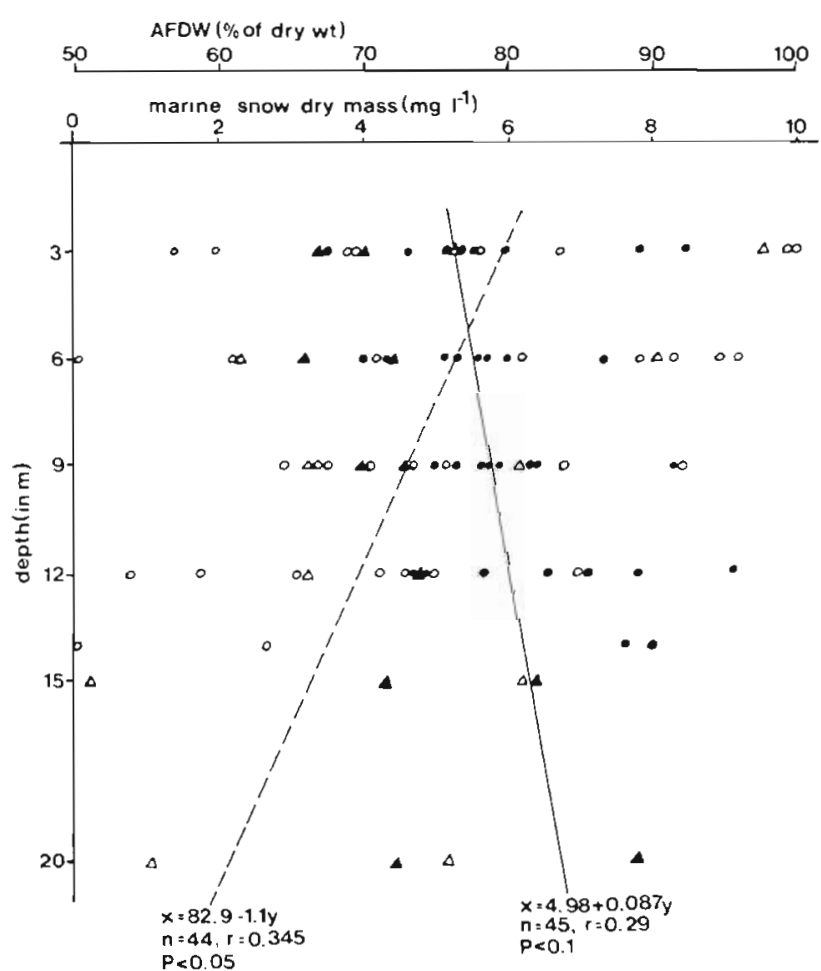

Fig. 1 Dependence of marine snow parameters on sampling depth. Solid line: regression for marine snow dry mass vs depth; corresponding data points indicated by closed symbols. Broken line: regression for marine snow organic matter $(\%$ ash-free dry wt of dry wt) vs depth; corresponding data points given by open symbols. Triangles: Stn F; circles; Stn MA; for details on sampling positions consult Herndl \& Peduzzi (1988)

with depth. While at $3 \mathrm{~m}$ depth $80 \%$ of marine snow dry wt was organic material this percentage dropped to $60 \%$ at $20 \mathrm{~m}$ depth (Fig. 1).

\section{Heterotrophic microorganisms and CHO-content of marine snow and surrounding water}

The microheterotrophic community in marine snow, as well as in the surrounding water, was dominated by heterotrophic bacteria, choanoflagellates and monads. 
In marine snow the microheterotrophic density was always higher than that of the ambient water (EF $>1$ ) (Table 1) and varied over 2 orders of magnitude, depending on the sampling method (see 'Material and Methods'). Microbial densities 1 order of magnitude higher were obtained when marine snow was allowed to settle in the storage vials prior to collection for analysis (Table 1). Despite this methodological variation introduced, microbial density varied considerably, even between consecutive days. No group in the microbial community examined had accumulated to an extent significantly greater than that of any other (Kruskal-Wallis, $p>0.2$ ). Maximum EF-values were obtained in marine snow kept in a $500 \mathrm{ml}$ storage vial in the dark at in situ temperature $\left(18^{\circ} \mathrm{C}\right.$ ) for $4 \mathrm{~d}$ (Table 1).

Microbial density in marine snow exhibited an inconsistent pattern between various depth layers during most of the sampling dates. After wind-induced mixing of the water column on 24 June, however, an exponential increase in bacterial density with depth was detected in marine snow on 25 and 30 June (Fig. 2a). During this period, monads were the most abundant eukaryotes in marine snow in the upper layers of the

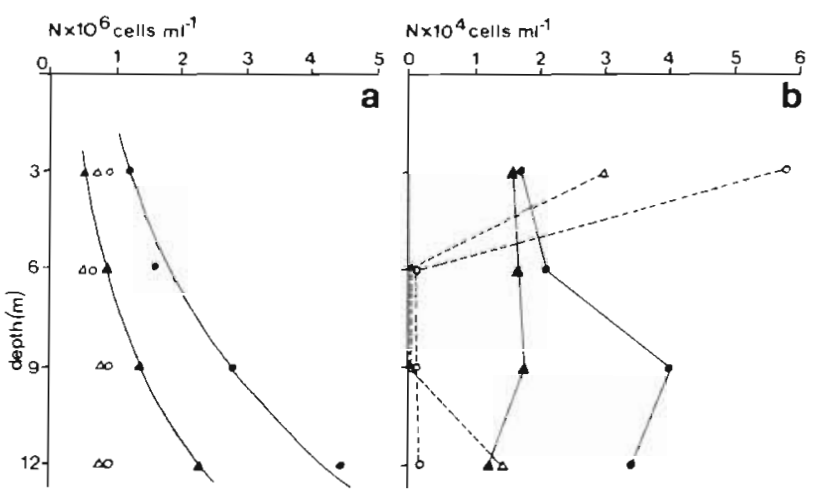

Fig. 2. Abundance of heterotrophic bacteria (a), and nanoflagellates (b) on marine snow after wind-induced renewal of water body. In (a), bacterial densities of the ambient water are indicated by open symbols (circles, 25 Jun, triangles, 30 Jun). In (b) choanoflagellate density is given by closed symbols; open symbols are for monads (circles, 25 Jun, triangles, 30 Jun)

water column while in deeper horizons choanoflagellates were the most prominent eukaryotes (Fig. 2b).

No significant differences in the biovolume of marine snow bacteria and free-living bacteria, respectively,

Table 1. Mean microbial density ( $\pm \mathrm{SD}) \mathrm{ml}^{-1}$ marine snow and enrichment factors (EFs) averaged over the water column during consecutive days

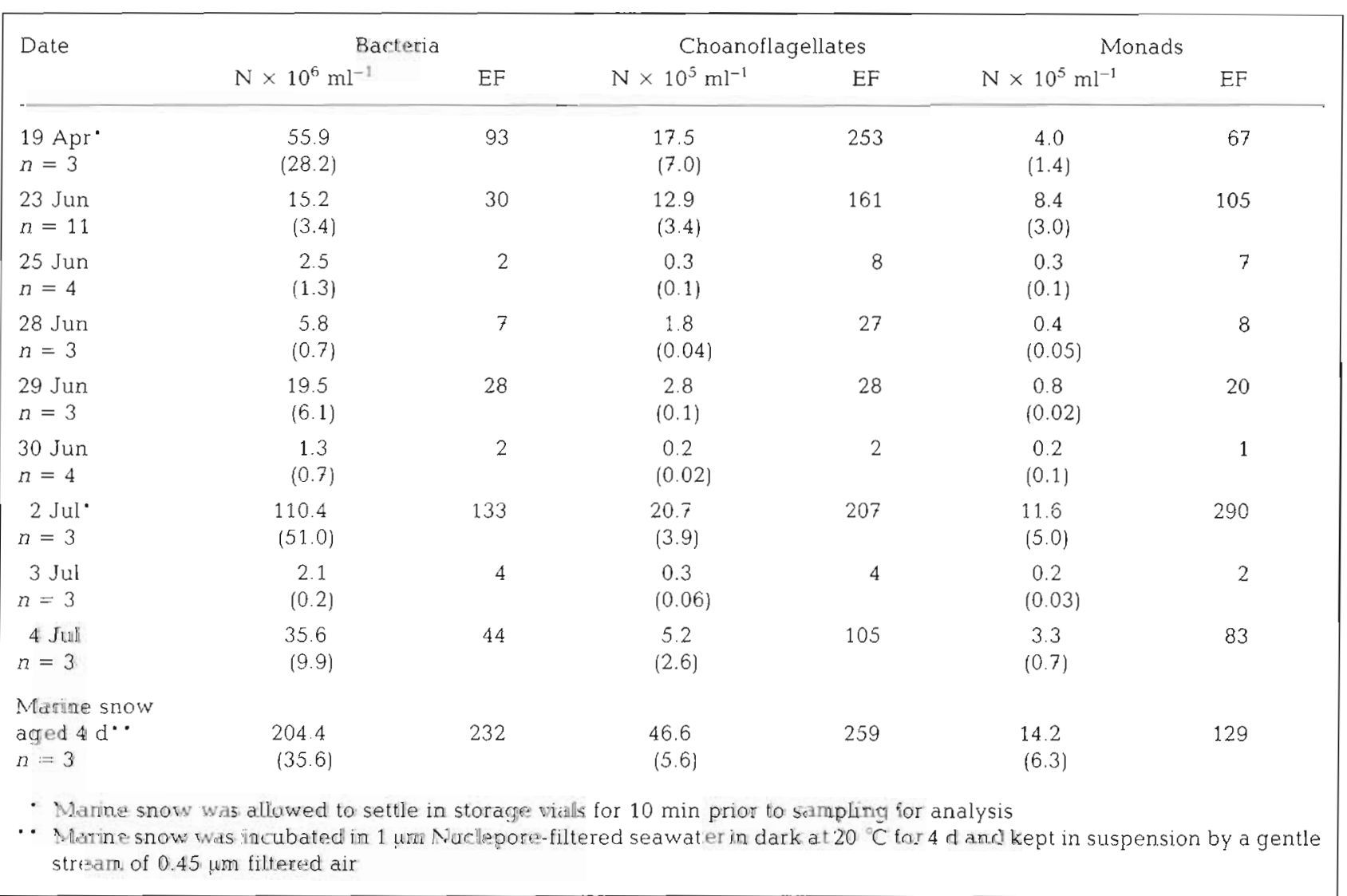


were found between sampling dates. Therefore, the volumes of marine snow bacteria were pooled regardless of sampling date as well as free-living bacteria. Mean bacterial biovolume for the 2 categories (i.e. rods and cocci) were higher in marine snow than in the surrounding water For rod-shaped bacteria, mean volume in marine snow was $0.25 \mu \mathrm{m}^{3}$ ( $\mathrm{SD}=0.05, n=350$ ), and therefore significantly higher than that of ambient water $\left(\overline{\mathrm{x}}=0.195 \mathrm{um}^{3}, \mathrm{SD}=0.038, n=325\right.$, ANOVA, $p<0.005)$. The corresponding volumes for coccoid bacteria were $0.067 \mu^{3}(\mathrm{SD}=0.009, n=175)$ in marine snow and $0.042 \mu^{3}$ (SD $=0.009, n=185$, ANOVA, $p<0.001$ ). Both groups of flagellates, however, did not differ significantly in volume between marine snow and ambient water (choanoflagellate mean volume: $11.43 \mu^{3} ; \mathrm{SD}=1.9 ; n=270 ;$ mean monad volume: $2.46 \mu \mathrm{m}^{3} ; \mathrm{SD}=0.83, n=236$ ).

Total carbohydrate content (TCHO) of marine snow averaged $251 \mathrm{ug} \mathrm{TCHO} \mathrm{ml}^{-1}$ (marine snow) $(\mathrm{SD}=43.8$, $n=10$ ) with no discernible pattern between depth layers; however, TCHO in marine snow was found to be enriched by a factor of 304 as compared to the surrounding water $\left(\overline{\mathrm{x}}=0.82 \mu \mathrm{g} \mathrm{TCHO} \mathrm{ml}^{-1}\right)$.

\section{$\mathrm{O}_{2}$-flux mediated by marine snow and surrounding water}

In situ measurements of $\mathrm{O}_{2}$-fluxes mediated by marine snow revealed a gross primary production (GPP) ranging from 3 to $23 \mu \mathrm{g} \mathrm{O} \mathrm{mg}^{-1}$ (marine snow AFDW) $\mathrm{h}^{-1}$ (Fig. 3). Highest marine snow associated $\mathrm{O}_{2}$ production rates were obtained in the $6 \mathrm{~m}$ layer, lowest values for the $9 \mathrm{~m}$ horizon. Although PAR levels at $12 \mathrm{~m}$ depth were only about half the levels of the $9 \mathrm{~m}$ horizon, GPP in marine snow was higher in the deeper layer. $\mathrm{O}_{2}$ consumption rates of marine aggregates varied within a more narrow range throughout the water column. Mean $\mathrm{O}_{2}$ consumption averaged over depths amounted to 1.35 $\mu \mathrm{O} \mathrm{O}_{2} \mathrm{mg}^{-1}$ (marine snow AFDW) h-1 $(\mathrm{SD}=0.2, n=16$ ) on 27 June; for 28 June a mean consumption of $3.7 \mu \mathrm{g} \mathrm{O}_{2}$ $\mathrm{mg}^{-1}$ (marine snow AFDW) $\mathrm{h}^{-1}(\mathrm{SD}=1.6, n=16) \mathrm{was}$ calculated. These consumption rates were 2.5 and 7 times, respectively, the mean consumption obtained under laboratory conditions. In laboratory incubations, mean $\mathrm{O}_{2}$ consumption was $0.54 \mu \mathrm{g} \mathrm{O}_{2} \mathrm{mg}^{-1}$ (marine snow AFDW) h ${ }^{-1}(\mathrm{SD}=0.19, n=9)$.

\section{Influence of decomposing marine snow on free-living microbes}

In the incubation flasks containing marine snow, free-living rod-shaped bacteria increased rapidly in number until $20 \mathrm{~h}$ after starting the incubation, while cocci did not exhibit such a pronounced reaction during the initial incubation phase. For the initial period $(0$ to $13 \mathrm{~h}$ ) of the incubation, rods increased from 6.1 to 33.9 $\times 10^{5}$ cells m $\mathrm{m}^{-1}$ and cocci from 7.0 to $16.9 \times 10^{5}$ cells $\mathrm{ml}^{-1}$, corresponding to a mean generation time $(\mathrm{g})$ for rods of $5.4 \mathrm{~h}$ and $10.5 \mathrm{~h}$ for cocci. During this period, rods increased in the control jar (containing $1 \mathrm{um}$ fil-
Fig. 3. Marine-snow-associated dark $\mathrm{O}_{2}$-respiration and gross primary production (GPP) measured in situ. For each depth, mean and SD of 4 replicate measurements are given. Photosynthetically active radiation (PAR) indicated by open triangles
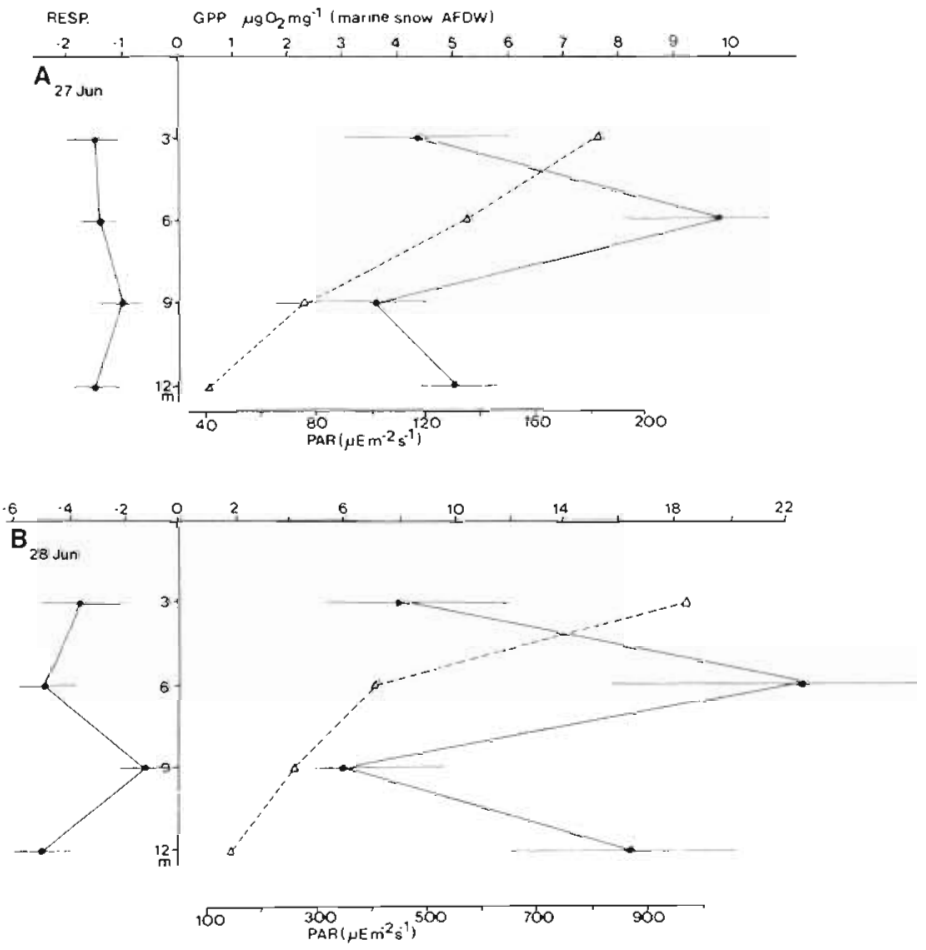
tered seawater only) from 3.5 to $6.9 \times 10^{5}$ cells $\mathrm{ml}^{-1}$ ( $g=13.9 \mathrm{~h}$ ) while cocci increased from 4.4 to $20.6 \times 10^{5}$ cells $\mathrm{ml}^{-1}(\mathrm{~g}=6 \mathrm{~h})$. The observed increase in bacterial biomass in the marine snow flasks was attributed to rods (Fig. 4 a). Thereafter, rod-shaped bacterial density dropped off rapidly to $3 \times 10^{5}$ cells $\mathrm{ml}^{-1}(\mathrm{SD}=1.5) 53 \mathrm{~h}$ after starting the experiment. In the subsequent period, total bacteria fluctuated in a very narrow range (Fig. 4a) with densities 2 to 3 times the bacterial abundance in the control. Biovolume of free-living rods incubated in the marine snow jars increased from $0.377 \mu^{3}$ $(\mathrm{SD}=0.112, n=178)$ at the beginning of the incubation to $0.459 \mu^{3} \quad(\mathrm{SD}=0.108, n=156)$ (ANOVA, $\mathrm{p}<0.01) 4 \mathrm{~h}$ after starting the incubation. After $34 \mathrm{~h}$, rod-shaped bacteria, however, decreased again in volume approaching their initial size (mean $=0.361 \mu \mathrm{m}^{3}$, $\mathrm{SD}=0.19, n=285$ ). No such changes in biovolume were noticed in coccoid bacteria or in the bacterial community of the control.

The corresponding development of the 2 dominant nanoflagellate categories (choanoflagellates and monads) are shown in Fig. $4 \mathrm{~b}$. In the marine snow chambers choanoflagellates increased continuously from $<10^{3}$ cells $\mathrm{ml}^{-1}$ at the beginning to $23 \times 10^{3}$ cells $\mathrm{ml}^{-1}$ after $53 \mathrm{~h}$ when they reached their peak density. Concurrent with the decline in choanoflagellate abundance, monads appeared, reaching densities up to $10^{6}$ cells $\mathrm{ml}^{-1}$. Monad biomass remained relatively stable from $72 \mathrm{~h}$ after starting the experiment to the end. In terms of carbon, monads maintained a biomass of 300 to $400 \mu \mathrm{g} \mathrm{C}^{-1}$ in the marine snow chambers during the second half of the incubation, which is about twice the bacterial biomass (Fig. 4b). In the control, maximum choanoflagellate biomass (ca $100 \mathrm{~h}$ after the beginning of the incubation) exceeded the peak biomass of choanoflagellates in the marine snow jars containing marine snow. Monads in the control maintained a biomass only one third of that of the marine snow incubations. No significant changes were found in the biovolumes of either category of nanoflagellates during the course of the incubation in either the control or in the marine snow jars. Mean choanoflagellate volume was $17.8 \mu \mathrm{m}^{3}$ ( $\left.\mathrm{SD}=1.4, n=75\right)$, average monad volume was $0.84 \mu \mathrm{m}^{3}(\mathrm{SD}=0.21, n=78)$.

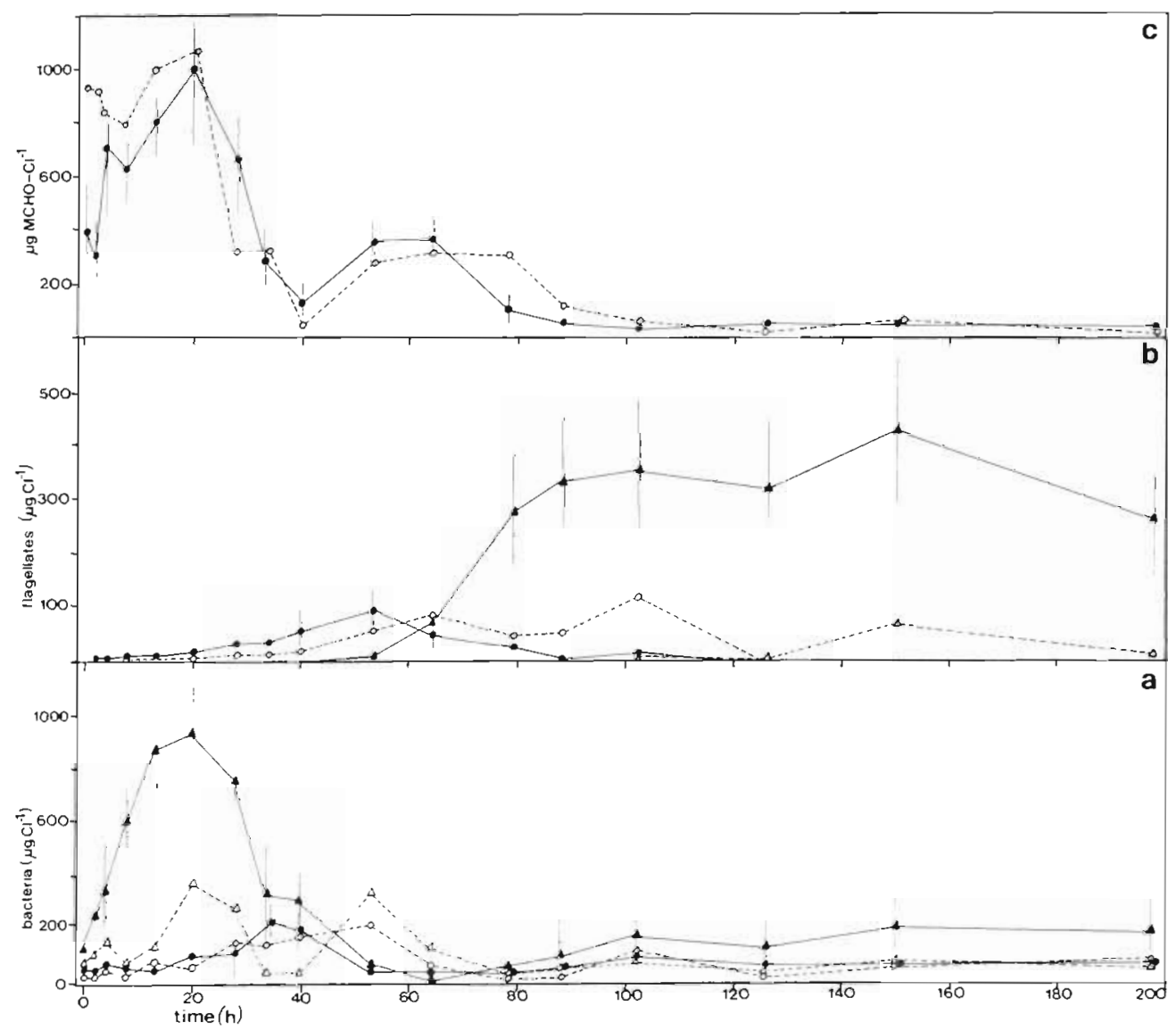

Fig. 4. Batch cultures with marine snow. (a) Development of free-living bacterial biomass in incubation media triangles: rodshaped bacteria, circles: cocci. (b) Development of flagellate biomass; triangles: monads, circles; choanoflagellates. (c) Course of dissolved MCHO concentration. Closed symbols indicate mean (SD) of 3 replicate incubations; open symbols stand for control to which no marine snow was added 
Dissolved monocarbohydrate (DMCHO) concentrations in both marine snow chambers and control revealed similar trends (Fig. 4c). During the first $4 \mathrm{~h}$ of incubation, however, $\mathrm{DMCHO}$-concentrations in the marine snow jars were about 3 times lower than the value of the control. DMCHO increased during the first $24 \mathrm{~h}$ and subsequently declined rapidly to concentrations below $200 \mu \mathrm{g} \mathrm{MCHO}-\mathrm{Cl}^{-1}$. The following small peak in DMCHO reached only about one third the height of the initial peak; thereafter, DMCHO concentrations remained well below $100 \mu \mathrm{g} \mathrm{MCHO}-\mathrm{C}^{-1}$ in both control and marine snow chambers during the latter stage of the incubation.

\section{DISCUSSION}

Abundance of marine snow in the water column of the Northern Adriatic Sea was shown to range from 3 to $9 \mathrm{mg}$ (marine snow dry wt) $1^{-1}$ in 1987, and is therefore similar to the mean value of $5 \mathrm{mg}$ (marine snow dry $w \mathrm{t}$ ) $\mathrm{l}^{-1}$ reported for the preceding year (Herndl \& Peduzzi 1988). Unlike the previous study, the lack of a pronounced thermocline led to a continuous increase in marine snow dry mass with depth (Fig. 1). This increase in dry mass is compensated by decreasing organic matter content with depth (Fig. 1). Based on the regression given in Fig. 1, at $3 \mathrm{~m}$ depth mean marine snow dry mass amounts to $5.3 \mathrm{mg} \mathrm{l}^{-1}$ with an average organic matter content of $80 \%$ or $4.2 \mathrm{mg} \mathrm{l}^{-1}$. At $20 \mathrm{~m}$ depth (ca $4 \mathrm{~m}$ above bottom) the $6.7 \mathrm{mg}$ marine snow dry wt contains only $61 \%$ organic matter or $4.1 \mathrm{mg} \mathrm{l}^{-1}$. The combined effect of microbial decomposition of the organic matrix of marine snow during sedimentation. and the attachment of resuspended inorganics may be responsible for this alteration.

Considerable variations in microbial density of marine snow particles were detected between consecutive days (Table 1). Stable weather conditions with low current velocities favor the development of a rich microbial community on/in marine snow while wind induced currents lead - at least partly - to a renewal of the water body, as indicated by changes in temperature and salinity (data not shown). Such an event was observed on 24 June, from 29 to 30 June and in the evening of 2 July. As demonstrated in Table 1, on each consecutive day marine snow microbes exhibited EF values between 1.3 and 4 . These values are considerably lower than the EF value obtained during more stable weather conditions. The rapid increase of the EF during the period following such an event may indicate rapid microbial colonization of recently developed marine snow. It should be noted, however, that all EF values of marine snow are conservative estimates since the samples were always diluted with surrounding water. Generally, ca one order of magnitude higher EF values were obtained if the marine snow was allowed to settle in the storage vials prior to analysis, indicating the dilution effect of surrounding water (Table 1). The settling period for marine snow of 10 min seems to be too short to account for significant microbial growth.

The degree of development of the microheterotrophic food chain was quantified using the ratio (heterotrophic nanoflagellate biomass/bacterial biomass) $\times$ 100. Fig. 5 presents the development of the microheterotrophic food chain during the course of marine snow incubation; for comparison, indices are also given for marine snow particles and the surrounding water. In the incubation media containing marine snow, ratios of $>100$ were maintained most of the time, suggesting that additional food sources other than freeliving bacteria were exploited by the nanoflagellate population. The indices of both the control medium and the surrounding water are similar to values reported for eutrophic or stratified waters of various regions (Sorokin 1977, Linley et al. 1983, Davoll \& Silver 1986). Extremely high ratios of $>200$ were also recorded for marine snow in April and at the end of June (Fig. 5). In general, enforced renewal of the water body by unstable weather conditions leads to lower ratios in marine snow.

As stated by Smetacek (1985), nutrient-depleted diatom blooms rapidly release cellular material into the surrounding water leading to flake formation. These flakes may aggregate further and reach dimensions of up to a few cm. In the Northern Adriatic Sea, marine snow rapidly increases in abundance during April which coincides roughly with the decay of the diatom bloom and the change from a 'new' to a 'regenerating' system (a concept first introduced by Dugdale \& Goering 1967). Marine snow (of biological origin) may therefore be considered as a typical sign of the regenerating phase in the Northern Adriatic Sea. While new systems are based on material resources transported by the environment, in regenerating communities the material resource is not necessarily lost from the system (Smetacek \& Pollehne 1986). In the latter, the bulk of primary production is based on shortterm recycling, implying that the microbial loop plays an important role in system respiration. All these criteria are fulfilled by marine snow aggregations.

The water column - considered a regenerating system during summer - is modified due to unstable weather conditions which enforce the renewal of the water body. These events shift the pelagic phase toward a new system with a diminished nanoflagellate population, resulting in flagellate/bacteria ratios typical for new systems. Due to the high growth rates of nanoflagellates in waters where marine snow is abundant (discussed below), the former stage of the system 


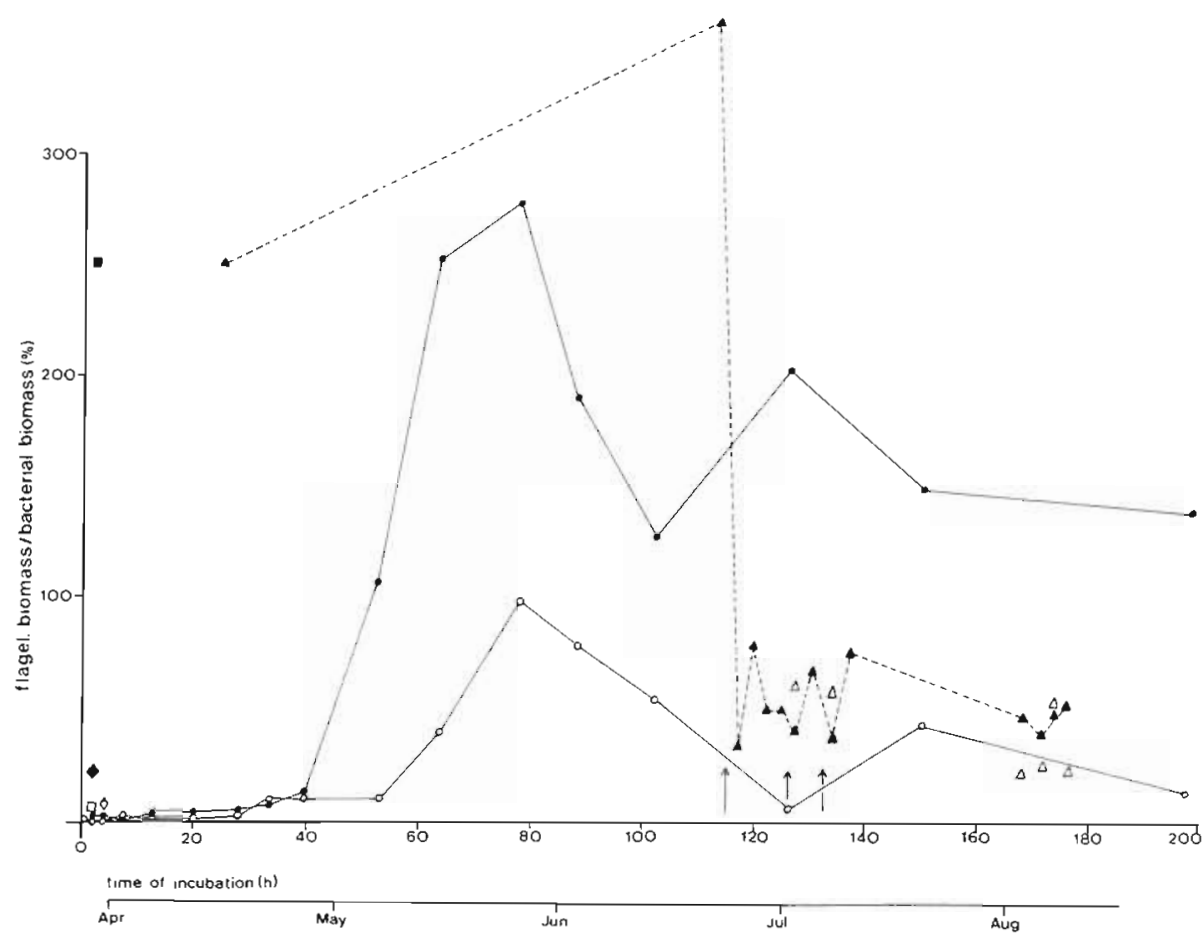

Fig. 5. Ratio of the degree of the development of microheterotrophic food chains - (nanoflagellate biomass/bacterial biomass) $x$ 100 - during batch culture experiment. Closed circles: marine snow incubation; open circles: controls Triangles: ratios obtained from in situ sampling; closed triangles, ratios for marine snow; open triangles, ratios of surrounding water. Arrows: storm events (for explanation see text). For comparison ratios are given for marine snow and surrounding water sampled off Trieste-Aurisina ( $\mathbf{\square}, \square)$, and for coral reef waters: ( space between branches of Acropora sp. and $(\diamond) 1 \mathrm{~m}$ above the coral head (data derived from Schiller \& Herndl in press) is established again rapidly. As pointed out by Smetacek \& Pollehne (1986), mucus release (of phytoand zooplankton) may favor the development of shortcircuit nutrient cycles and small-scale nutrient patches in the pelagic environment. Such a mucus-based system with a high microbial activity is the interstitial space between coral branches (Schiller \& Herndl in press).

Incubation experiments were designed to assess the microbial response of the surrounding water to marine snow. In the present experiment marine snow dry mass $1^{-1}$ was ca 4 to 10 times higher than recorded for the Northern Adriatic Sea (Herndl \& Peduzzi 1988, this study). The initial, pronounced increase in bacterial biomass of free-living rods in the incubation media containing marine snow does not simply reflect detachment of marine snow bacteria since the $200 \mathrm{ml}$ marine snow-seawater slurry added contained only about 3.6 $\times 10^{7}$ bacteria or $4.5 \%$ of the bacterial population of the incubation media $(800 \mathrm{ml})$. In terms of carbon, $5.1 \mu \mathrm{g} \mathrm{C}($ or $5 \%$ ) of marine snow bacteria were added to $96 \mu \mathrm{g} \mathrm{C}$ of free-living bacteria. Hence we obtained a ca 5 fold increase in bacterial biomass within $20 \mathrm{~h}$. It seems unlikely that detached marine snow bacteria contribute significantly to the free-living bacterial population (Fig. 4a). The peak in bacterial biomass is caused almost exclusively by the rod-shaped bacterial population. This may indicate that rods took up nutrients more actively than cocci. This pattern is consistent with observations made in other environments. It is generally believed that rods are characteristic for waters of high nutritive value. Kogure et al. (1987) demonstrated that large bacteria grow much faster than small cells $(<0.6 \mu \mathrm{m})$ and that the former are the main contributers to the turnover of organic matter. In the experiment presented in Fig. 4a, coccoid bacteria reached their maximum biomass $14 \mathrm{~h}$ after the biomass peak in rods. At that time (34 h after starting the incubation) rod-shaped bacterial biomass had already diminished - most likely due to enhanced nanoflagellate predation. Rods started to decrease when the nanoflagellate population entered exponential growth.

Based on these incubation experiments, parameters describing growth can be derived (Table 2). Bacteria and nanoflagellate growth rates $(\mu)$ und growth yields (Y) obtained in our incubation experiments are among the highest reported in the literature. However, the growth yields for nanoflagellates derived from our incubations are most likely overestimates since the bacterial population was probably still growing during the observed decrease in biomass. Therefore, the total consumption of bacteria is higher than the net removal of bacterial biomass. Even taking these overestimates into account, marine snow enhances microbial growth and leads to ca 3 times higher growth rates than incubations with unenriched media (Table 2). In our experiment, the control media were sampled in the same parcel of water in which the marine snow was sampled. Since Herndl \& Peduzzi (1988) detected a net release of dissolved organic carbon from marine snow into the surrounding water, we suggest that the control medium was at least partly enriched by marine snow derived 
Table 2. Comparison of parameters of growth and feeding in heterotrophic bacteria and nanoflagellates obtained from marine snow batch cultures with data given in literature. Gross grow rate $(\mu)=\left(\ln X_{t}-\ln X_{0}\right) / t$, where $X_{t}$ and $X_{0}=$ density of organisms at end and beginning of time interval $\mathrm{t}\left(\mathrm{in} \mathrm{h}\right.$ ); $\mathrm{Y}_{\mathrm{N}} \equiv$ (eventual number of flagellates/initial number of bacteria) $\times 100 ; \mathrm{Y}_{\mathrm{B}}=(\mathrm{flagellate}$ C-biomass/bacterial C-biomass) $\times 100_{i}$ - not determined

\begin{tabular}{|c|c|c|c|c|}
\hline Source & $\begin{array}{c}\text { Bacteria } \\
\mu\left(h^{-1}\right)\end{array}$ & $\mu\left(h^{-1}\right)$ & $\begin{array}{l}\text { oflagell } \\
Y_{N}(\%)\end{array}$ & $Y_{B}(\%)$ \\
\hline $\begin{array}{l}\text { This study } \\
\text { marine snow } \\
\text { control }\end{array}$ & $\begin{array}{l}0.104 \\
0.067\end{array}$ & $\begin{array}{l}0.05^{\mathrm{a}} 0.086^{\mathrm{b}} \\
0.05^{\mathrm{a}} 0.04^{\mathrm{b}}\end{array}$ & $\begin{array}{r}30.4 \\
7.3\end{array}$ & $\begin{array}{l}35.5 \\
16.1\end{array}$ \\
\hline Andersen \& Sorensen (1986) & 0.035 & 0.027 & - & - \\
\hline Bratbak (1987) & - & - & - & 24 \\
\hline Fenchel (1986) & - & 0.19 & 37 & 27 \\
\hline $\begin{array}{l}\text { Herndl \& Velimirov (1986) } \\
\text { coral mucus } \\
\text { control } \\
\text { a Value for choanoflagellates } \\
\text { b Value for monads }\end{array}$ & $\begin{array}{l}0.077 \\
0.038\end{array}$ & $\begin{array}{l}- \\
-\end{array}$ & $\begin{array}{l}- \\
-\end{array}$ & $\begin{array}{l}- \\
-\end{array}$ \\
\hline
\end{tabular}

organic nutrients. This assumption is supported by a similar incubation experiment in which decomposition of coral mucus was investigated (Herndl \& Velimirov 1986); a mean bacterial growth rate in the control jar of $0.038 \mathrm{~h}^{-1}$ was obtained using similar experimental conditions. Therefore, we conclude that marine snow enhances not only microbial growth on/in the organic matrix of the particles but also favors microbial activity of the surrounding water

The reason for such favorable conditions for microbial life is the concentration of easily utilizable organic matter in marine snow. TCHO-concentrations in marine snow were 300 times higher than in the same volume of surrounding water. In the batch culture, the available dissolved MCHO was utilized within $100 \mathrm{~h}$ (Fig. 4c). At the end of the incubation, MCHO concentrations were close to the detection limit of the method used.

In marine snow, the high concentration of microbial biomass with autotrophic and heterotrophic compartments may considerably influence overall pelagic metabolic processes during summer. Compared to the in situ mean $\mathrm{O}_{2}$-consumption in dark chambers of $2.5 \mu \mathrm{g}$ $\mathrm{mg}^{-1}$ (marine snow AFDW) $\mathrm{h}^{-1}, \mathrm{O}_{2}$-consumption in the laboratory was 2 to 7 times lower. In the laboratory marine snow was incubated in $0.45 \mu \mathrm{m}$ Nuclepore filtered seawater; thus organisms not associated with marine snow were excluded. In situ, however, planktonic organisms from the surrounding water were unavoidably enclosed during sampling of marine snow and consequently interfered with the in situ measurements.

In conjunction with marine snow dry mass data, these measurements enable us to estimate roughly the contribution of marine snow to overall water column processes. Mean midday GPP of the water column amounted to $15 \mathrm{mg} \mathrm{C} \mathrm{m}{ }^{-3} \mathrm{~h}^{-1}$, water column respiration to $5.6 \mathrm{mg} \mathrm{C} \mathrm{m}{ }^{-3} \mathrm{~h}^{-1}$. Mean marine snow content over the water column averaged $4.1 \mathrm{mg}$ (marine snow AFDW) $l^{-1}$ during investigation. Average GPP of marine snow over the water column meaned $3.54 \mu \mathrm{g} \mathrm{C}$ $\mathrm{mg}^{-1}$ (marine snow AFDW) $\mathrm{h}^{-1}$, or $14.5 \mathrm{mg} \mathrm{C} \mathrm{m}^{-3} \mathrm{~h}^{-1}$. In situ mean respiration rate was $0.94 \mu \mathrm{g} \mathrm{C} \mathrm{mg}^{-1}$ (marine snow AFDW) $\mathrm{h}^{-1}$, or $3.8 \mathrm{mg} \mathrm{C} \mathrm{m}^{-3} \mathrm{~h}^{-1}$. Although these values are only crude estimations and do not allow extrapolation of the GPP of the system. they indicate that more than $90 \%$ of the pelagic GPP is bound to marine snow aggregations and ca $70 \%$ of the mineralization activity is mediated by marine-snowassociated microbes. The high contribution of marine snow to pelagic GPP during summer may be explained by its autotrophic community, which exhibits EF values of up to 1000 (Herndl \& Peduzzi 1988). Knauer et al. (1982) found that up to $58 \%$ of the nearshore primary production may occur in association with marine snow, and Alldredge \& Cohen (1987), using $\mathrm{O}_{2}$-microelectrodes, clearly documented the intensive $\mathrm{O}_{2}$-production and consumption of individual marine snow particles. Considering the high abundance and the large size of marine snow in the waters of the Northern Adriatic Sea during summer, the calculated contribution of these aggregations to overall pelagic metabolism seems reasonable.

In summary, these marine snow aggregates seem to be vital signs of regeneration systems in which the microbial loop is an important pathway in the pelagic food web (Azam et al. 1983, Smetacek \& Pollehne 1986). These fragile aggregations escape conventional sampling methods. They form nutrient patches and 
stimulate microbial life not only within the aggregations but also in the surrounding water More intensive and sensitive sampling methods capable of detecting such nutrient patches will make it possible to resolve the heterogeneity of the pelagic environment, in which the function of mucus as a binding agent has not yet received adequate attention.

Acknowledgements. I thank Ian Jenkinson, Peter Peduzzi, Christian Schiller, Gottfried Schinner, Wolfram Tertschnig and Peter Tusnik for diving assistance and help in laboratory experimentation. Farooq Azam and 2 anonymous reviewers read and improved this paper. The hospitality of the staffs of the Marine Biology Station Piran and the Stazione Biologia Marina at Trieste-Aurisina is gratefully acknowledged. Bill Lorenz improved the English text, and Sigrid Neulinger drew the figures. Financial support was provided by the 'Fonds zur Forderung der wissenschaftl. Forschung' (Project Nos. P6138 and P6695).

\section{LITERATURE CITED}

Alldredge, A. L., Cohen, Y. (1987). Can microscale chemical patches persist in the sea? A microelectrode study of marine snow, fecal pellets. Science 235: 689-691

Amy, P. S. Caldwell, B. A., Soeldner, A. H., Morita, R. Y., Albright, L. J. (1987). Microbial activity and ultrastructure of mineral-based marine snow from Howe Sound, British Columbia. Can. J. Fish. Aquat. Sci. 44: 1135-1142

Andersen, P., Sorensen, H. M. (1986). Population dynamics and trophic coupling in pelagic microorganisms in eutrophic coastal waters. Mar. Ecol. Prog. Ser 33: 99-109

Azam, F., Fenchel, T., Field, J. G., Gray, J. S., Meyer-Reil, L.A., Thingstad, F (1983). The ecological role of watercolumn microbes in the sea. Mar Ecol. Prog. Ser. 10: $257-263$

Beers, J. R., Trent, J. D., Reid, F. M. H., Shanks, A. L. (1986). Macroaggregates and their phytoplankton components in the Southern California Bight. J. Plankton Res. 8: 475-487

Biddanda, B. A. (1985). Microbial synthesis of macroparticulate matter. Mar. Ecol. Prog. Ser. 20: 241-251

Biddanda, B. A. (1988). Microbial aggregation and degradation of phytoplankton-derived detritus in seawater. II. Microbial metabolism. Mar. Ecol. Prog. Ser. 42: 89-95

Biddanda, B. A., Pomeroy, L. R. (1988). Microbial aggregation and degradation of phytoplankton-derived detritus in seawater. I. Microbial succession. Mar. Ecol. Prog. Ser 42: $79-88$

Borsheim, K. Y., Bratbak, G. (1987). Cell volume to cell carbon conversion factors for a bacterivorous Monas sp. enriched from seawater Mar. Ecol. Prog. Ser 36: 171-175

Bratbak, G. (1987). Carbon flow in an experimental microbial ecosystem. Mar. Ecol. Prog. Ser. 36: 267-276

Burney, C. M. Sieburth, J. McN. (1977). Dissolved carbohydrates in seawater. II. A spectrophotometric procedure for total carbohydrate analysis and polysaccharide estimation. Mar. Chem. 5: 15-28

Caron, D. A., Davis, P. G., Madin, L. P., Sieburth, J. McN. (1982). Heterotrophic bacteria and bacterivorous protozoa in oceanic macroaggregates. Science 218: 795-797

Davoll, P. J., Silver, M. W (1986). Marine snow aggregates life history sequence and microbial community of abandoned larvaceān houses from Monterey Bay, California. Mar Ecol. Prog. Ser. 33: 111-120
Dugdale, R. C., Goering, J. J. (1967). Uptake of new and regenerated forms of nitrogen in primary productivity. Limnol. Oceanogr. 12: 196-206

Eisma, D. (1986). Flocculation and de-flocculation of suspended matter in estuaries. Neth. J. Sea Res. 20: 183-199

Fenchel, T (1986). The ecology of heterotrophic microflagellates. Adv. Microb. Ecol. 9: 57-97

Fowler, S. W. Knauer, G. A. (1986). Role of large particles in the transport of elements and organic compounds through the oceanic water column. Prog. Oceanogr. 16: 147-194

Herndl, G. J., Velimirov, B. (1986). Microheterotrophic utilization of mucus released by the Mediterranean coral Cladocora cespitosa. Mar. Biol. 90: 363-369

Herndl, G. J., Peduzzi, P. (1988). The ecology of amorphous aggregations (marine snow) in the Northern Adriatic Sea I. General considerations. P.S.Z.N.I.. Mar. Ecol. 9: 79-90

Hobbie, J. E., Daley, R. J., Jasper, S. (1977). Use of Nuclepore filters for counting bacteria by fluorescence microscopy. Appl. environ. Microbiol. 33: 1225-1228

Jackson, T. A. (1975). Humic matter in natural water and sediments. Soil Sci. 119: 56-64

Johnson, K. M., Sieburth, J. MCN. (1977). Dissolved carbohydrates in seawater I. A precise spectrophotometric analysis for monosaccharides. Mar. Chem. 5: 1-13

Knauer, G. A., Hebel, D. Cipriano, F. (1982). Marine snow: major site of primary productivity in coastal waters Nature, Lond. 300: 630-631

Kogure, K., Simidu, U., Taga, N., Colwell, R. R. (1987). Correlation of direct viable counts with heterotrophic activity for marine bacteria. Appl. environ. Microbiol. 53: 2332-2337

Krom, M. D., Sholkovitz, E. R. (1977). Nature and reactions of dissolved organic matter in the interstitial waters of marine sediments. Geochim. Cosmochim. Acta 41. 1565-1573

Lee, S. Fuhrman, J. A. (1987). Relationships between biovolume and biomass of naturally-derived marine bacterioplankton. Appl. environ. Microbiol. 53: 1298-1303

Linley, E. A. S., Newell, R. C., Lucas, M. I. (1983). Quantitative relationships between phytoplankton, bacteria and heterotrophic microflagellates in shelf waters. Mar Ecol. Prog. Ser. 12: 77-89

McCave, I. N. (1984). Size spectra and aggregation of suspended particles in the deep ocean. Deep Sea Res. 31: 329-352

Oviatt, C. A., Rudnick, D. T., Keller, A. A., Sampou, P. A., Almquist, G. T (1986). A comparison of system $\left(\mathrm{O}_{2}\right.$ and $\mathrm{CO}_{2}$ ) and $\mathrm{C}-14$ measurements of metabolism in estuarine mesocosms. Mar Ecol. Prog. Ser. 28: 57-67

Paerl, H. W. (1975). Microbial attachment to particles in marine and freshwater ecosystems. Microb. Ecol. 2: 73-83

Peduzzi, P. (1987). Beitrag Epiphyten-konsumierender Prosobranchier zum Energiefluß und Kohlenstoffumsatz in einem mediterranen Seegras-Ökosystem. Ph. D. thesis, Univ. of Vienna

Poutanen, E. L., Morris, R. J. (1983) A study of the formation of high molecular weight compounds during the decomposition of a field diatom population. Estuar coast. Shelf Sci. 17: $189-196$

Reuter, J. H., Perdue, E. M. (1977). Importance of heavy metalorganic matter interactions in natural waters. Geochim. Cosmochim. Acta 41:325-334

Schiller, C., Herndl, G. J. (in press). Evidence of enhanced microbial activity in the interstitial space of branched corals: possible implications for coral metabolism. Coral Reefs

Sholkovitz, E. R. (1976). Flocculation of dissolved organic and inorganic matter during the mixing of river water and seawater. Geochim. Cosmochim. Acta 40: 831-845 
Silver, M. W., Shanks, A. L., Trent, J. D. (1978). Marine snow: microplankton habitat and source of small-scale patchiness in pelagic populations. Science 201: 371-373

Silver, M. W., Gowing, M. M., Brownlee, D. C., Corliss, J. O (1984). Ciliated protozoa associated with oceanic sinking detritus. Nature, Lond. 309: 246-248

Smetacek, V (1985). Role of sinking in diatom life-history cycles: ecological, evolutionary and geological significance Mar. Biol. 84: 239-251
Smetacek, V., Pollehne, F. (1986). Nutrient cycling in pelagic system: a reappraisal of the conceptual framework. Ophelia 26: $401-428$

Sorokin, X I. (1977). The heterotrophic phase of plankton succession in the Japan Sea. Mar. Biol. 41: 107-117

Svoboda, A., Ott, J. A. (1983). In situ measurement of community metabolism in littoral marine systems. In: Gnaiger, E. Forstner, H. (eds.) Polarographic oxygen sensors. SpringerVerlag, Berlin, p. 285-297

This article was submitted to the editor; it was accepted for printing on July 24, 1988 